$\mathrm{A} \mathrm{J}_{\cos } \mathrm{H}$

Received : 22.08.2017

Revised : 06.11.2017

Accepted : 13.11.2017

Members of the Research Forum

Associated Authors:

${ }^{1}$ Department of Horticulture,

Faculty of Agriculture,

Annamalai University,

ANNAMALAI NAGAR (T.N.)

INDIA

Email: kiransharaj@gmail.com

Author for correspondence : ASWATHY SURESH

Department of Horticulture,

Faculty of Agriculture,

Annamalai University,

ANNAMALAI NAGAR (T.N.)

INDIA

Email : ponnumkm@gmail.com
THEASIAN JOURNALOF HORTICULTURE

Volume 12 | Issue 2 | December, 2017 | 202-205

Visit us -www.researchjournal.co.in

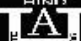

$\mathrm{S}$

RESEARCH PAPER

DOI : 10.15740/HAS/TAJH/12.2/202-205

\title{
Effect of pruning intensities on yield of guava (Psidium guajava L.) cv. LUCKNOW 49
}

\section{ASWATHY SURESH AND ARUMUGAM SHAKILA ${ }^{\mathbf{1}}$}

ABSTRACT : An investigation on the effect of pruning intensities on yield of guava cv. Lucknow 49 was undertaken at the Department of Horticulture, Annamalai University, Tamil Nadu. Five years old guava trees of the cultivar Lucknow 49 were taken for this investigation. Different pruning levels and time of pruning viz., pruning $10 \mathrm{~cm}, 20 \mathrm{~cm}, 30 \mathrm{~cm}$ of apical shoots during mid March, mid April, mid May comprised the treatment combinations. Among the various pruning treatments, it was observed that pruning $30 \mathrm{~cm}$ of apical shoots during mid March proved to be the best in increasing the yield and yield attributes like fruit weight and fruit yield per tree followed by $20 \mathrm{~cm}$ level of pruning during mid March. The results of the present study indicate that the effect of various pruning treatments on the yield of guava cv. LUCKNOW 49 was more pronounced in season II when compared to season I. In conclusion, pruning $30 \mathrm{~cm}$ of apical shoots during mid March can be recommended for commercial fruit production with enhanced yield in guava cv. LUCKNOW 49.

KEY WORDS : Pruning, Pruning intensities, Quality attributes

HOW TO CITE THIS ARTICLE : Suresh, Aswathy and Shakila, Arumugam (2017). Effect of pruning intensities on yield of guava (Psidium guajava L.) cv. LUCKNOW 49 . Asian J. Hort., 12(2) : 202-205, DOI : 10.15740/HAS/TAJH/12.2/202-205. 